\title{
Ohjaussuhteen tyylit puntarissa
}

\begin{abstract}
एy
Opinnäytetyöprosessissa ohjaajan ja ohjattavan suhde on kriittinen tekijä. Millainen ohjaustyyli tukee ohjattavaa ja antaa samalla tilaa tutkijaksi kasvulle?
\end{abstract}

OHJAUSPROSESSIN ONNISTUMINEN on yksi tärkeimpiä asioita opinnäytetyön valmistumisen ja laadun näkökulmasta, ja sen merkitys vain korostuu monivuotisissa väitöskirjahankkeissa.

Ohjaus ei kuitenkaan aina suju ongelmitta, käy ilmi esimerkiksi kyselytutkimuksesta, jonka opetusministeriö toteutti vuonna 2005. Siihen haastateltiin yli 3800 Suomen yliopistojen ja korkeakoulujen jatko-opiskelijaa (Hiltunen \& Pasanen 2006). Tutkimus osoitti, että jatkokoulutuksen suurimmat ongelmat koskevat nimenomaan ohjausta ja perehdyttämistä: jopa 75 prosenttia jatko-opiskelijoista koki perehdytyksen riittämättömäksi. Lisäksi yli puolet vastaajista kertoi, että ohjaaja ei ollut keskustellut ohjattavan kanssa tarpeeksi muun muassa tutkimuksen teoriasta tai metodologisista kysymyksistä.
Ohjaajan interventiot ovat erityisen merkityksellisiä ohjausprosessin alussa, jolloin ohjattava yleensä tarvitsee ohjaajansa tukea eniten (Vehviläinen 2014). Oikein kohdennettu alkuperehdytys edistää tutkimustyötä, ja tieteelliseen ajatteluun perehdyttäminen ja tiedeyhteisön jäseneksi kasvaminen on hyvä käynnistää heti ohjausprosessin alkuvaiheessa (Pasonen-Seppänen 2008). Ohjaajan ja ohjattavan välisen ohjaussuhteen on opinnäytetyön edetessä tarkoituksenmukaista muuttua sen myötä, kun ohjattava kehittyy oman alansa asiantuntijaksi (Vehviläinen 2014).

Ohjausprosessin toimivuuteen saattavat vaikuttaa monet erilaiset, niin ohjaajaa kuin ohjattavaa koskevat tekijät, kuten persoonallisuuden piirteet, motivaatio ja vuorovaikutustaidot. Tutkimusryhmät ovat 


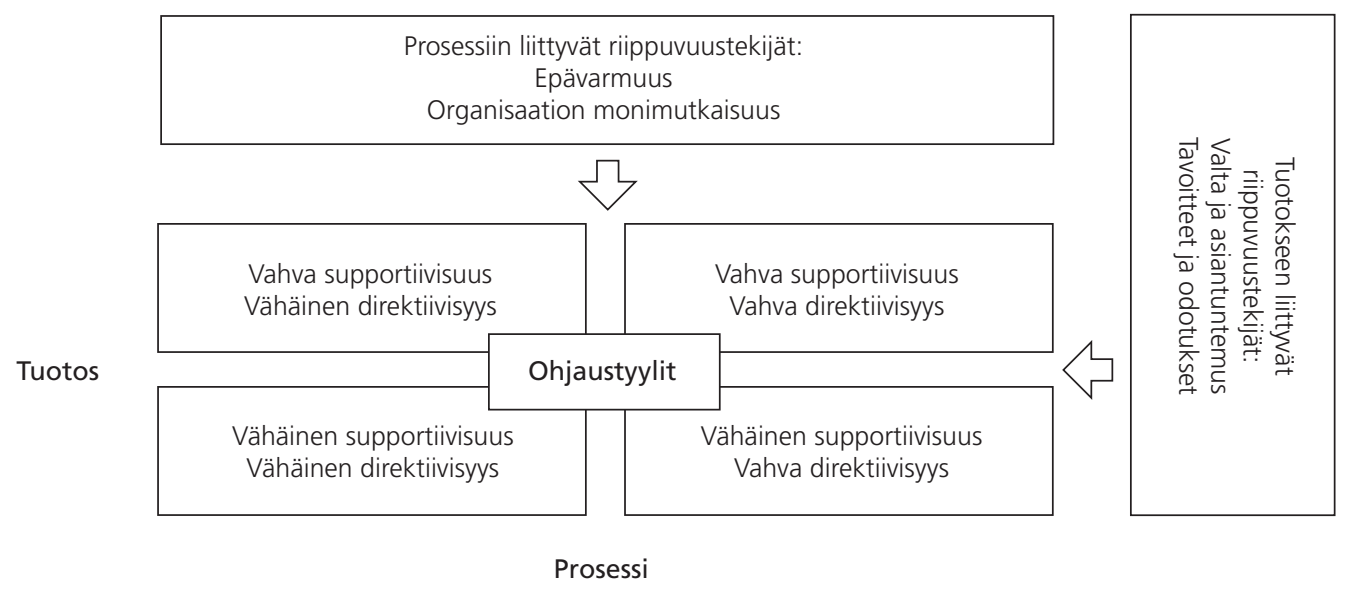

Kuvio 1. Ohjaustyylit ja riippuvuustekijät Boehen (2016) mukaan.

yhä monikulttuurisempia, joten jäsenten erilaiset kulttuuritaustat voivat vaikuttaa siihen, millainen ohjaustyyli on toimivin (Jung \& Takeuchi 2013; Pellegrini, Scandura \& Jayaraman 2010). Tiedeyhteisössä on perinteisesti arvostettu ohjaajan sisältöosaamista, koulutusta ja akateemista menestystä. Yhä enemmän kiinnitetään huomiota myös ohjauksen laatuun ja ohjaajan pedagogisiin taitoihin.

Ohjauksen orientaatiolla tarkoitetaan systemaattista toimintalinjaa, joka säätelee, mitä ohjaustilanteessa tehdään ja sanotaan (Vehviläinen 2014). Ohjaustyössä on useita erilaisia orientaatioita, jotka riippuvat ohjauksen kontekstista, tavoitteista ja ohjaajan teoreettisesta suuntautumisesta. Syvällinen ymmärrys orientaatioista voi auttaa ohjaajaa valitsemaan mielekkäitä pedagogisia keinoja.

Näkökulmatekstissämme pohdimme, miten taitava ohjaaja toimii erilaisissa ohjaustilanteissa. Tarkastelemme tutkimuskirjallisuuden näkökulmasta, millaisia erilaisia ohjaustyylejä opinnäytetyön ohjaajan on mahdollista käyttää: mikä toimii hyvin eri ohjattavien kanssa, ja millaisissa ohjaustyyliä koskevissa asioissa ohjaajan on syytä olla valppaana.

\section{OHJAUSTYYLIT JA RIIPPUVUUSTEKIJÄT}

Ohjaussuhteeseen sisältyy aina epävarmuutta ja tilannesidonnaisia vuorovaikutustekijöitä, eikä yksi ohjaustyyli sovi kaikkiin tilanteisiin. Australialainen Dirk Michael Boehe (2016) tarkastelee ohjausta liiketaloustieteen näkökulmasta. Hän on pyrkinyt hahmottamaan ohjaustyön tilannesidonnaisuutta organisaatiotutkimuksesta lainatun kontingenssiteorian avulla. Laatimassaan nelikentässä (kuvio 1) Boehe erittelee ohjaustyylejä ja niihin vaikuttavia tekijöitä.

Olemme valinneet tarkastelumme lähtökohdaksi Boehen mallin, koska siinä ohjaussuhdetta ei tarkastella vain yksilötasolla erilaisten persoonallisuuspiirteiden ja pyrkimysten kohtaamisena vaan suhteena, jonka kontekstina on organisaatio. Toivomme mallin tarkastelusta olevan hyötyä sekä ohjaajille että ohjattaville, jotka voivat ohjaussuhteen kuluessa käyttää nelikenttää tunnistaakseen suhteen osa-alueita ja kehittämistä vaativia kohtia kulloisessakin ohjaussuhteen organisatorisessa kontekstissa.

Nelikentässä ohjaustyylien ulottuvuudet ovat vahva ja heikko supportiivisuus sekä runsas ja vähäinen direktiivisyys. Boehe tarkoittaa supportiivisuudella ohjattavan työtä sekä tiedollisesti että käytännössä tukevaa ohjaustyyliä ja direktiivisyydellä vahvasti ohjattavan työskentelyä ohjailevaa tyyliä. Tuotosta ja prosessia koskevat muuttujat vaikuttavat ohjaussuhteeseen eri tavoin.

Tarkastelemme kutakin neljää ohjaustyyliä siitä näkökulmasta, millaisissa tilanteissa niitä esiintyy: minkä tekijöiden vaikutuksesta ohjaaja päätyy tietynlaiseen 
OHJAAJATKIN

\section{SAATTAVAT SUHTAUTUA \\ KUNNIANHIMOISESTI}

OHJATTAVIINSA.

ohjaustyyliin? Siinä missä Boehen malli itsessään on ensisijaisesti kuvaileva, kiinnostuksemme kohdistuu myös siihen, kuinka hyödyntää mallia ohjaustyössä.

\section{OHJAUSTYYLIN VALINTAA KOSKEVAT TEKIJÄT}

Pohdimme kunkin nelikentän mukaista ohjaustyyliä ennen kaikkea ohjaajan ja ohjattavan välisen suhteen näkökulmasta. Ohjaustyylien ominaispiirteisiin vaikuttaa lisäksi ryhmätaso, esimerkiksi tutkimusryhmä toimintaperiaatteineen. Tiedeyhteisön järjestäytyminen, kuten tiedekunnan tai laitoksen hierarkkisuus, taas vaikuttavat siihen, millaiseksi ohjaajan ja ohjattavan välinen suhde muodostuu. Siten Boehen malli on merkityksellinen sekä ohjaajan ja ohjattavan välisen suhteen että ryhmän ja organisaation tasolla.

\section{Vahva direktiivisyys - vahva supportiivisuus}

Ohjaajan ja ohjattavan välisessä suhteessa sekä direktiivisyys että supportiivisuus voivat korostua. Vahvasti direktiivisessä ohjaussuhteessa ohjaaja vaikuttaa tehokkaasti ohjattavansa työskentelyyn. Silloin ohjaussuhde edellyttää yleensä, että ohjattavat työskentelevät ohjaajan fyysisessä läheisyydessä, ja yhdellä ohjaajalla on suhteellisen vähän ohjattavia (Boehe 2016). Vahva direktiivisyys vaatii lisäksi, että ohjattavan on helppo yhtyä ohjaajansa ideoihin ja ehdotuksiin. Helppous voi olla ohjattavan avoimuutta uusille ideoille ja kykyä ajatella asioita uusista, toisten esittämistä näkökulmista.

Varaukseton myöntyminen voi myös johtua ohjattavan heikoista pystyvyysuskomuksista (Bandura 1977; 1997), jolloin hän saattaa pitää ohjaajansa ideoita aina parempina kuin omiaan tarkastelematta sen kriittisemmin ideoiden laatua.
Ohjattavan itsesäätelytaidot (Baumeister \& Vohs 2004) voivat vaikuttaa ohjaussuhteen direktiivisyyteen. Kun ohjattava toistuvasti tekee selväksi, että ei ole kyennyt viemään tutkimustyötään itsenäisesti eteenpäin, ohjaaja saattaa kokea tarvetta antaa aiempaa yksityiskohtaisempia ohjeita työn edistämiseksi.

Ohjaustyyliltään voimakkaan direktiivinen ohjaaja voi myös olla voimakkaan supportiivinen. Boehe (2016) viittaa supportiivisuudella ensisijaisesti ohjaajan toimintaan, joka tähtää ohjattavan työskentelyn lopputuotoksen, opinnäytetyön, laadun parantamiseen. Boehen (2016) mukaan tällaisen ohjaussuhteen syntyyn vaikuttavat monet tekijät. Ohjattava saattaa turvautua ohjaajansa tukeen erityisesti, kun ohjaaja on alansa tunnustettu asiantuntija, jolta voi ikään kuin loputtomasti ammentaa tutkimustyön kannalta tarkoituksenmukaista teoreettista ja metodologista osaamista (Lee 2008; Wilson 1999).

Ohjaajatkin saattavat suhtautua kunnianhimoisesti ohjattaviinsa, minkä vuoksi he haluavat tarjota näille kaiken mahdollisen tuen. Jos ohjattavasta kehittyy ohjaajansa tuella hyvä tutkija, ohjaaja saa hänestä myöhemmin luotettavan yhteistyökumppanin.

Vahvasti direktiiviseen ja supportiiviseen ohjaussuhteeseen voi sisältyä monia ongelmia. Vaikka ohjaustyyli auttaisi tutkimusprosessin alkuvaiheessa ohjattavaa pääsemään kiinni tehtäväänsä, tilanne voi kehittyä ongelmalliseksi, jos ohjaajan direktiivisyyden ja supportiivisuuden aste ei tutkimustyön edetessä vähitellen pienene. Liiallisen direktiivisyyden ja supportiivisuuden myötä ohjattavan on vaikea "omistaa" omaa oppimistaan ja kasvaa itsenäiseksi, ohjaajastaan riippumattomaksi tutkijaksi.

Kuten Hakkarainen (2000) esittää, ohjaaja voi tukea ohjattavansa itsenäistymistä tarjoamalla tälle tilaisuuksia osallistua aitoihin asiantuntijakäytäntöihin ilman kokonaisvastuuta oppimisprosessista tai sen lopputuloksesta. Asteittain syvenevän osallistumisen ja kehittyvän taidon tasoon suhteutetun tuen avulla ohjattavan vastuu omasta oppimisesta ja tuotoksesta lisääntyy (Hakkarainen 2000). Näin ohjattavasta voi kehittyä pätevä alansa asiantuntija, joka ei enää ole vain ohjaajansa jatke vaan aidosti itsenäinen toimija. 
OHJAAJAN VOI OLLA

VAIKEA SIET $\ddot{A} \ddot{A}$

TUTKIMUSPROSESSIIN

KUULUVAA

EPÄVARMUUTTA.

\section{Vähäinen direktiivisyys - vähäinen supportiivisuus}

Ohjaajan vähäinen direktiivisyys ja vähäinen supportiivisuus vaikuttaa ensi kuulemalta yhdistelmältä, joka viittaa ohjaajan täydelliseen välinpitämättömyyteen ja on omiaan tuottamaan onnettomia ja ajelehtivia opinnäytteiden tekijöitä. Tyytymättömyys ohjaussuhteeseen on usein sidoksissa ohjauksen vähäisyyteen tai puuttumiseen. Vahvaa direktiivisyyttä on kuitenkin hankala yhdistää tutkimusprosessiin, joka sisältää paljon epävarmuutta. Dobrow, Smith ja Posner (2011) esittävät, että osallistava ohjausmalli voi olla hedelmällisempi kuin vahva direktiivisyys siinä mielessä, että se kasvattaa ohjattavan motivaatiota.

Usein korostetaan opinnäytetyötä itsenäisenä prosessina, joka koulii itsenäisen tutkijan. Boehe (2016) esittää, että vähäinen direktiivisyys ja supportiivisuus ovat eräänlainen opinnäytetyöprosessin päätepiste, jossa ohjattava on vahvan ohjauksen avulla kehittynyt itsenäiseksi tutkijaksi. Tätä ajattelua vasten laissez faire -asenne ei näyttäisi sopivan ohjauksen alkumetreille.

Boehen mukaan vähäinen direktiivisyys ja vähäinen supportiivisuus opinnäytetyötään aloittelevan tutkijan ohjauksessa voi kuitenkin toimia, jos ohjattava integroituu alusta lähtien vahvasti tutkijayhteisöön ja seminaarityöskentelyyn. Tutkijayhteisö tarjoaa ohjattavalle mahdollisuuden omaksua tutkijoiden hiljaista tietoa ja toimintakulttuuria, joka tukee asiantuntijayhteisön jäseneksi kasvamista (Hakkarainen 2000). Vahva kollektiivinen tuki, mahdollisuus reflektoida tutkimuksen ongelmakohtia ryhmässä ja vertaisilta tuleva tutkimuskysymysten haastaminen vähentävät ohjaajan antaman kahdenkeskisen tuen ja ohjauksen merkitystä.
Vähäinen direktiivisyys ja supportiivisuus voivat käynnistää opinnäytetyön menestyksekkäästi silloinkin, kun ohjattava on jo hankkinut kokemusta tutkimuksen teosta ja on mahdollisesti ohjaajaansa perehtyneempi työnsä aihealueeseen, eikä kaikki asiantuntemus ole ohjaajalla. Ohjattava on useimmiten luonut varsinaisen ohjausprosessin ulkopuolella siteen johonkin osaamis- tai asiantuntijayhteisöön, jonka käytäntöihin hänen on mahdollista osallistua. Silloin alkuvaiheen vahva ohjausote voi pikemminkin olla luotaantyöntävää kuin kannustavaa. Keskeistä tässä suhteessa on, ettei vähäinen direktiivisyys ja supportiivisuus tarkoita samaa kuin estäminen tai lannistaminen. Pikemminkin ohjaaja näyttää vihreää valoa, muttei taluta tien yli.

\section{Vahva direktiivisyys - vähäinen supportiivisuus}

Vahvaan direktiivisyyteen ja vähäiseen supportiivisuuteen liittyy usein voimakas prosessin korostaminen, toisinaan tutkimuksen lopputuotoksen kustannuksella. Vahvalla direktiivisyydellä ohjaaja saattaa pyrkiä jäsentämään tehtäviä ja ohjausprosessia yhä paremmin ja tehokkaammin (Pearce \& Barkus 2004). Ohjaajan voi olla vaikea sietää tutkimusprosessiin kuuluvaa epävarmuutta, mitä hän peittää korostetun strukturoidulla ohjaustyylillä (Hofstede 2001). Mitä epävarmempi ja jäsentymättömämpi tutkimusasetelma on, sitä vaikeampi ohjaajan on kuitenkin lopulta kontrolloida tilannetta (Fiedler 1978).

Jos ohjattava on oman tutkimusalansa asiantuntija ja kokenut tutkija, ohjaussuhteeseen saattaa hiipiä kilpailun elementti, mikä voi entisestään vähentää ohjaajan supportiivisuutta (Deutsch 1985). Yleensä ohjaajan tuki ainakin yhdessä sovituissa tavoitteissa ja aikatauluissa edistää tutkimusprojektia, ja sen puute voi koitua haitalliseksi pätevällekin ohjattavalle (Pasonen-Seppänen 2008). Tällöin ohjaajan direktiivisyydellä voi olla paikkansa.

Ohjaajalta vaaditaan kuitenkin erityistä herkkyyttä, jotta ohjattavan vahva asiantuntijuus ei lisää ohjaajan omaa epävarmuutta, mikä saattaisi johtaa tarpeettoman vahvaan direktiivisyyteen sekä ohjattavan motivaation ja luovan ajattelun latistumiseen. 
JAETUT TAVOITTEET

\section{LIS $\ddot{A} \ddot{A} \ddot{A} T$ SISÄIST $\ddot{A}$}

MOTIVAATIOTA.

Vähäinen supportiivisuus voi myös liittyä tilanteisiin, joissa ohjaajalla ja ohjattavalla on hyvin erilaiset tavoitteet tutkimusprojektista tai tulevaisuudesta. Yhteisten tavoitteiden puuttuminen voi viedä osapuolia eri suuntiin ja johtaa jopa siihen, että ohjattava hylkää koko projektin.

Vähäinen supportiivisuus voidaankin nähdä ohjausprosessin luonnollisena päätepisteenä, jossa ohjattava on kehittynyt oman alansa asiantuntijaksi ja pystyy työskentelemään itsenäisesti. Ajatus on lähellä Hakkaraisen (2000) tarkastelemaa käsitystä oppimisesta identiteetin kehityksenä: ohjausprosessissa neuvotellaan tutkijayhteisön jäsenyydestä saatujen kokemusten merkityksestä, ja opinnäyteprosessin päätepisteeksi nähdään ohjattavan tutkijaidentiteetin kehittyminen. Tällaista tilannetta ei kuitenkaan pidä tavoitella ennenaikaisesti.

\section{Vähäinen direktiivisyys - vahva supportiivisuus}

Vähäisen direktiivisessä ja voimakkaan supportiivisessa ohjausprosessissa korostuu prosessin sijaan produkti, opinnäytetyön tuotos. Ohjaaja antaa ohjattavan päättää, millä keinoilla tulos saavutetaan, mutta pyrkii tekemään selväksi työskentelyn päämäärän. Vähäinen direktiivisyys lisää ohjattavan osallistumisen mahdollisuuksia: ohjaaja strukturoi ohjattavan toimintaa kuitenkaan rajaamatta käytössä olevia vaihtoehtoja (Hakkarainen 2000). Tällaisen suhteen on huomattu mahdollistavan ohjattavien luovien ongelmanratkaisukapasiteettien aktivoitumisen.

Päätöksentekoon osallistumisen on todettu lisäävän ohjattavien vastuuta omasta oppimisestaan ja vahvistavan heidän sisäistä motivaatiotaan, mikä taas johdattaa yhä parempaan suoriutumiseen tehtävistä (Dobrow, Smith \& Posner 2011; Hakkarainen 2000).
Boehe (2016) korostaa yhteisten tavoitteiden merkitystä nimenomaan supportiivisuuden kannalta. Jaetut tavoitteet lisäävät sisäistä motivaatiota, auttavat hahmottamaan kokonaisuutta ja suuntaavat keskittymistä prosessin kannalta keskeisiin asioihin (Zimmerman ym. 1992). Mitä selkeämmät yhteiset tavoitteet ohjaajalla ja ohjattavalla on, sitä todennäköisemmin he tukevat toisiaan.

Ohjaajan supportiivisuudella tarkoitetaan myös ohjattavan tunnekokemuksen kannattelemista (Vehviläinen 2014), ja supportiivinen ohjaustyyli on todettu erityisen hyödylliseksi, kun ohjausprosessissa ilmenee vaikeuksia. Ongelmia voivat esimerkiksi aiheuttaa tutkimusryhmäläisten erilaiset kulttuuritaustat ja niihin kytkeytyvät odotukset työyhteisön ja yliopisto-organisaation toimintakulttuurista. Kulttuurierot lisäävät organisaation kompleksisuutta, mikä osaltaan vaikeuttaa ohjaajan mahdollisuuksia vaikuttaa ohjattaviensa tutkimusprosesseihin (Jung \& Takeuchi 2013). Silloin toimivin ohjaussuhteen malli voi olla alhainen direktiivisyys, johon yhdistyy voimakas supportiivisuus.

Vaikka kannatteleva orientaatio mahdollistaa vaikeiden tilanteiden ja niihin liittyvien kokemusten tarkastelun ja sen myötä itsetuntemuksen lisääntymisen, liiallisen supportiivisuuden vaarana voi olla suhteen muodostuminen liian terapeuttiseksi. Kannattelevuus on perusteltua niin kauan kuin se edistää tutkimusprosessia. Pelkkä tunnekokemusten äärellä oleminen tuskin pitkällä tähtäimellä kuitenkaan on opinnäyteohjauksen tavoitteiden mukaista, vaan tarvitaan myös ongelmanratkaisuun tähtääviä interventioita.

Vehviläisen (2014) mukaan vaikeisiin tilanteisiin sisältyvien tunteiden vastaanottaminen ja hyväksyminen kiinteyttää ohjaussuhdetta, jolloin ongelmia voidaan ratkoa. Erityisesti ohjausprosessin alkupuolella ohjattava tarvitsee ongelmanratkaisussa paljon ohjaajansa tukea, kuten neuvoja ja palautetta omasta suoriutumisestaan (Vehviläinen 2014). Oikein ajoitetulla tuella ohjaaja voi haastaa ohjattavaansa asteittain syvenevään ongelmanratkaisuun, joka tukee ohjattavan oppimista, itsenäistymistä ja kasvamista päteväksi tieteentekijäksi (Hakkarainen 2000). 


\section{OHJaustyyli El $\dddot{A} \ddot{A}$}

\section{PROSESSIN KULUESSA.}

\section{OHJAUSPROSESSI YHTEISEN TARKASTELUN KOHTEEKSI}

Pyrkimyksenämme oli jäsentää ohjaustyylien kirjoa sekä eri ohjaustyylien vahvuuksia ja kriittisiä kohtia Boehen (2016) nelikentän pohjalta. Vaikka Boehen malli ei osoittautunut täysin yhteismitalliseksi muussa ohjausta käsittelevässä tutkimuskirjallisuudessa esitettyjen mallien kanssa, havaitsimme jonkinlaisia yhtymäkohtia esimerkiksi Vehviläisen (2014) ohjaustyön orientaatioihin sekä Hakkaraisen (2000) kuvaamaan asteittain syvenevään osallistumiseen.

Siinä missä Boehen malli on ensisijaisesti deskriptiivinen, pyrimme tuomaan esiin niitä näkökulmia, jotka voivat toimia ohjaajien ohjenuorana. Toivomme mallin rohkaisevan ohjaajia reflektoimaan ohjaussuhteitaan uudella tavalla, jotta he pystyvät yhä paremmin mukauttamaan ohjaustyylejään ohjattaviensa tarpeisiin ja tukemaan heidän asiantuntijuutensa kehittymistä ja itsenäistymistään tutkijana. Kun ohjaajat tiedostavat ohjaustyylejään ja niihin vaikuttavia tekijöitä, he voivat reflektoida kriittisesti omaa toimintaansa ja pyrkiä pois ohjaustyyleihinsä sisältyvistä sudenkuopista, niistä ei toivotuista lopputuloksista, jotka ovat seurausta ohjaajan kulloisenkin ohjaustyylin erityispiirteistä. Siten Boehen malli voi auttaa ymmärtämään ohjauksessa esiin tulevia tilanteita, joissa saatetaan tarvita korjausliikkeitä, jotta ohjattavasta kasvaa itsenäinen ja pätevä tieteentekijä.

Boehen mallissa ohjaustyyleihin yhdistyy tuotosta ja prosessia koskevia muuttujia. Ohjaajan ja ohjattavan välisessä suhteessa voimakkaan direktiivisessä ohjaustyylissä korostuu ohjattavan oppimisprosessin ohjaaminen. Tämä voi olla tarpeen muun muassa silloin, kun ohjattavan itseluottamus tai itsesäätelytaidot tai molemmat ovat heikot ja ohjaaja joutuu ottamaan voimakkaan roolin prosessin edistämisessä (Baumeister \& Vohs 2004).
Voimakkaan supportiivisessa ohjaustyylissä taas korostuu ohjauksen lopputuotos, opinnäytetyö. Sen omaksuminen on tyypillistä, kun opinnäytteen aihe on lähellä ohjaajan omia tutkimusaiheita ja menetelmiä (Boehe 2016). Ohjaajalla on tällöin parhaat mahdollisuudet ohjata työn tiedollista puolta, ja usein vahvat henkilökohtaiset, työn laatua koskevat intressit.

Sekä prosessiin että lopputuotokseen keskittyvää ohjausta tarvitaan, eikä kumpikaan ole sinänsä toista huonompi vaihtoehto. Tärkeintä on löytää eri ulottuvuuksien välinen tasapaino ja tiedostaa sekä ohjattavaa, ohjaajaa että tutkimusorganisaatiota koskevia asioita, jotka voivat säädellä prosessin tai produktin toteutumista.

Ohjaustyyli elää prosessin kuluessa. Voimakkaan direktiivinen ja supportiivinen ohjaustyyli on useimmiten hyvä ratkaisu ohjausprosessin alkuvaiheessa, kun ohjattavalla on vielä vajavainen käsitys niin prosessista kuin tutkimuksen sisällöstä, ja asiantuntijayhteisöön osallistumisen aste alhainen (Boehe 2016; Hakkarainen 2000).

Kun ohjaaja sekä tukee ohjattavansa ongelmanratkaisua ja tiedollista oppimista että auttaa prosessin etenemistä, työ pääsee hyvin käyntiin. Asteittain syvenevän osallistumisen myötä direktiivisyyden ja supportiivisuuden asteen tulisi kuitenkin vähitellen pienentyä, jotta ohjattavasta kehittyy itsenäinen toimija ja hän omaksuu tutkijan identiteetin (Boehe 2016; Hakkarainen 2000).

Todennäköisesti ohjattavan ja ohjaajan yhteinen tie ei kuitenkaan etene suoraan Boehen mallin mukaan, vaan ohjaussuhde elää sekä vertikaalisesti että horisontaalisesti ohjaajan ja ohjattavan ominaisuuksien, persoonallisuuden pirrteiden, vuorovaikutuksen ja laajempaan asiantuntija organisaatioon osallistumisen mukaan. Ohjaajan on joskus yhtä vaikea muuttaa ohjaustyyliään kuin vanhemman on päästää irti kasvavasta lapsestaan. Siksi Boehen esittämä ajatus, että ohjaaja ja ohjattava ottaisivat muutaman kerran ohjausprosessin aikana kontingenssimallin yhteisen tarkastelun kohteeksi, voi olla hyödyllinen. Näin ohjaussuhdetta koskevista muutostarpeista olisi helpompi keskustella ilman, että kumpikaan osapuoli kiusaantuu. 
Jotta ohjaajat osaisivat ottaa Boehen mallin käyttöön ohjauskeskusteluissaan, sitä voitaisiin aktiivisesti tuoda ohjaajien ja opettajien tietoisuuteen esimerkiksi oppilaitosten opetuksen kehittämispäivissä.

Usein ohjaustyylejä käsitellään lähinnä ohjaajan ja ohjattavan välisenä suhteena. Lisäksi niihin vaikuttavat tutkimusryhmä, tiedekunta ja tiedeyhteisö.

Vahva direktiivisyys on mahdollista, kun organisaatio on rakenteeltaan riittävän yksinkertainen eikä sen jäsenten välillä ole monimutkaisia hierarkioita, kun työntekijöiden tehtävät ovat selkeitä ja heidän välisensä suhteet sopuisia, kun ohjaajien työmäärä on kohtuullinen, ja ohjattavat työskentelevät ohjaajansa fyysisessä läheisyydessä. Näin on kuitenkin

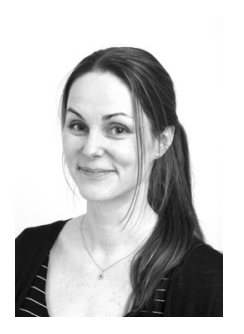

ELINA WEISTE

VTT, erikoistutkija

Työterveyslaitos

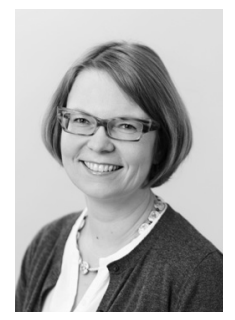

SANNA AALTONEN

VTT, dosentti, erikoistutkija Nuorisotutkimusverkosto harvoin: sekä organisaatiot että ohjattavat prosessit ovat monimutkaisia, ohjattavia on paljon, ja ohjaajien ja ohjattavien väliset etäisyydet voivat olla pitkiä.

Korkeakouluorganisaation taso näyttää siten asettavan monenlaisia esteitä voimakkaan direktiiviselle ohjaustyylille. Se sopii yhteen siihen ajattelutapaan, että opiskelijat ovat lähtökohtaisesti varsin itseohjautuvia, eikä ohjaajan velvollisuutena ole kuljettaa ohjattavaansa opinnäyteprosessin läpi. Aina oppilaitosten organisaatioissa ei ole päinvastaiselle ajattelutavalle edes puitteita. Ristiriitaista on se, että opiskelijat itse kokevat ohjauksen saatavuuden ja riittävyyden opinnäytetöiden kriittisimmäksi ongelmaksi.

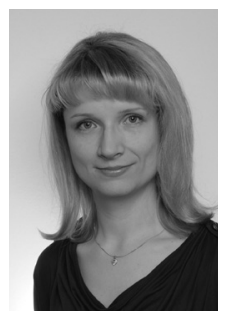

HANNA SAVOLAINEN-PELTONEN

LT, dosentti, naistentautien ja synnytysten erikoislääkäri, vs. kliininen opettaja HYKS Naistenklinikka ja Helsingin yliopisto

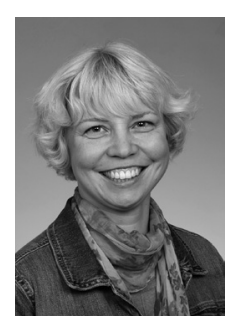

MELISA STEVANOVIC

VTT, MuM, tutkijatohtori Helsingin yliopisto 
Bandura, A. (1977). Self-efficacy. Towards a unifying of behavioural change. Psychological Review 84(2), 191-215

Bandura, A. (1997). Self-efficacy: The exercise of control. New York: W.H. Freeman and Company.

Baumeister, R. \& Vohs, K. (2004). Handbook of SelfRegulation: Research, theory, and applications. New York: Guilford Press.

Boehe, D.M. (2016). Supervisory styles: A contingency framework. Studies in Higher Education 41(3), 300-414

Deutch, M. (1985). Distributive justice: A social psychological perspective. New Haven: Yale University Press.

Dobrow, S.R., Smith, W.K. \& Posner, M.A. (2011). Managing the grading paradox: Leveraging the power of choice in the classroom. Academy of Management Learning and Education 10(2), 261-276.

Fiedler, F.E. (1978). The contingency model and the dynamics of the leadership process. Teoksessa Berkowitz, L. (toim.) Advances in experimental social psychology. New York: Academic Press, 59-112.

Hakkarainen, K. (2000). Oppiminen osallistumisen prosessina. Aikuiskasvatus 20(2), 84-98.

Hiltunen, K. \& Pasanen, H.-M. (2006) Tulevat tohtorit. Jatko-opiskelijoiden kokemukset ja arviot tohtorikoulutuksesta 2005. Opetusministeriön julkaisuja 48, 20-49.

Hofstede, G.H. (2001). Culture's consequences: Comparing values, behaviors, institutions and organizations across nations. Thousand Oaks, CA: Sage.
Jung, Y. \& Takeuchi, N. (2013). Relationships among leader-member exchange, person- organization fit and work attitudes in Japanese and Korean organizations: Testing a cross-cultural moderating effect. International Journal of Human Resource Management 25(1), 23-46.

Lee, A. (2008). How are doctoral students supervised? Concepts of doctoral research supervision. Studies in Higher Education 33(3), 267-281.

Pasonen-Seppänen, S. (2008). Jatko-opintojen ohjaus: hyviä ohjauskäytänteitä jatko-opintojen ohjaajille. Kehittämishankeraportti, Jyväskylän ammattikorkeakoulu.

Pearce, C.L. \& Barkus, B. (2004). The future of leadership: Combining vertical and shared leadership to transform knowledge. Academy of Management Executive 18(1), 47-59.

Pellegrini, E.K., Scandura, T.A. \& Jayaraman V. (2010) Cross-cultural generalizability of paternalistic leadership: An expansion of leader-member exchange theory. Group and Organization Management 35 (4), 391-420.

Vehviläinen, S. (2014). Ohjaustyön opas. Yhteistyössä kohti toimijuutta. Helsinki: Gaudeamus.

Wilson, A.L. (1999). Creating identities of dependency: Adult education as a knowledge-power regime. International Journal of Lifelong Education 18(2), 85-93.

Zimmerman, B.J., Bandura, A. \& Martinez-Pons, M. (1992). Self-motivation for academic attainment: The role of self-efficacy beliefs and personal goal setting. American Educational Research Journal 29(3), 663-676. 